I University of Edinburgh, Edinburgh, United Kingdom

lisa.mccormick@ed.ac.uk

https://orcid.org/oooo-00oI-8I65-5647

Lisa McCormick'

\title{
THE PERFORMATIVE POWER OF IDEAS: JEFFREY ALEXANDER AS AN ICONIC INTELLECTUAL
}

It has already been established that Jeffrey C. Alexander is an influential scholar. In previous reviews of his work, he has been described as a 'leading figure' (Eyerman, 2004: 25) in contemporary social theory and hailed as the 'pioneer' (Lynch \& Sheldon, 20I3: I) of a new sociological approach with a distinctive theoretical agenda. His interventions have been recognized as groundbreaking whether they are credited with "turning the discipline [of sociology] on its feet" (Cordero, Carballo \& Ossandón, 2008: 523), or characterized as 'refounding' American Sociology through internal transformation (Kurasawa, 2004: 53). His imprint on the strong program in cultural sociology is so recognizable that it is sometimes called the 'Alexander School' (Emirbayer, 2004: 5) or the 'Alexander group' (Inglis, Blaikie \& Wagner-Pacifici, 2007: I0). My aim in this paper is not to contest these claims; the accolades, awards and titles Alexander has accumulated over the years provide irrefutable empirical evidence of his reputation and standing. Rather, my argument is that the case has been understated, and that Alexander is becoming an iconic intellectual.

According to Bartmanski (20I2), intellectuals are said to be 'iconic' when they have a lasting, widespread and irreversible impact. They are identified as 'foundational' because of the galvanizing effect of their ideas rather than the gatekeeping function they might have performed in their professional capacity. Following Bartmanski (20I2) and Zelinsky (20I8), my discussion will not explain away Alexander's emerging iconicity by focusing on materialistic con- 
ditions, opportunity structures, academic habitus, or network advantage. Instead, I will offer a look inside iconization. As a long-term member of the 'Alexander group,' I have witnessed the charisma process by observing the development of Alexander's social authority and participating in countless events where he displayed his distinctive performative style. After discussing the history of the strong program from an insider's point of view, I will conclude by considering its future and some of the challenges that lie ahead.

I went to UCLA in 2000 to pursue a PhD in sociology under Alexander's supervision after completing a master's degree at Oxford University where I had explored the sociological aspects of the commissioning and performance of contemporary classical music. Alexander was clearly not a sociologist of music, but that did not present a problem; I had become increasingly dissatisfied with the perspectives of Becker and Bourdieu, despite their prominence in sociological studies of the arts, and the broader cultural approach held more promise. In the fall semester, I enrolled in Alexander's course Sociology 204 "Cultural Sociology: Basics and Explorations" and worked my way through the canonical readings on the syllabus. This formal training was complemented with the occasional gatherings of the 'Culture Club' where graduate students at various stages of the degree would discuss works in progress in Alexander's home. These seminars had the same intellectual excitement of classes with Alexander on campus, but they were intensified by the circumstances. An invitation to the 'Culture Club' meant membership in an inner circle with privileged access to Alexander. Released from the time constraints and bureaucratic conventions of the classroom, we could explore ideas for their own sake. The off-campus location also reinforced the group's sense of oppositional identity and the importance of our endeavor. It was not a secret society, but it was 'underground' for all intents and purposes, and the main condition of membership was 'being sufficiently cultural.'

The first item in my course reader for 'Cultural Sociology 204' explained what 'being cultural' meant. It was a typescript essay called "The Strong Program in Cultural Theory: Elements of a Structural Hermeneutics," and it would be published three years later under a slightly different title (Alexander \& Smith, 2003). This manifesto not only stated the theoretical commitments to which I would pledge allegiance; it also provided an origin story for the strong program that encoded the sacred and profane in the discipline and articulated the reformation project into which I was enlisted. Our quest was noble because it could be traced to each of the founding figures of the discipline: the humanism in Marx's early writings, the interpretive approach in Weber's religious sociology, and the emphasis on the symbolic dimension of modern society in Durkheim's later works. Mainstream sociologists who were 'culturally unmusical' (Alexander \& Smith, 2003: I5) could be forgiven for their ignorance, but not the advocates of the 'sociology of culture.' These false prophets and their weak 
programs had to be exposed; Bourdieu, the Birmingham School and the production perspective were peddling reductionist explanations that obscured the role of culture and dodged the vital theoretical issues. To counter their polluting influence, the strong program had assembled the "resources of ideational "purity'" (Bartmanski, 20I 2: 43I) by recovering the hermeneutic project started by Geertz, Sahlins and Ricoeur. We took courage in the knowledge that steps towards a "bona fide strong program" (Alexander \& Smith, 2003: 2I) had already been achieved and celebrated the first fruits of the strong program's analytic advances.

In 200I, I transferred to Yale University where Alexander had accepted an endowed professorship. It was not easy to leave UCLA, and many questioned the rationality of my decision to move across the country and start over at a new institution. Any lingering doubts I might have had were extinguished when I saw how quickly Alexander re-established an intellectual hotbed in this new setting. With the founding of the Center for Cultural Sociology (CCS), the underground seminars transformed into weekly public workshops often featuring guest speakers. Before long an exchange was set up with the University of Konstanz and the program of events extended to include international conferences.

Whatever the occasion, Alexander's improvised theorizing was as stimulating and complex as his written prose; frequently he would pause mid-thought to insert what felt like a footnote, and even these would involve several layers of parentheses within parentheses. He would not pick sides in debates but identify the deeper reasons why they emerged in the first place, focusing attention on more fundamental issues. Leaning back with his hands folded behind his head, he could trace the threads of logic in an argument and unfold their implications in the way that the great chess players operate several moves ahead of the game in play. His intellect was even more intimidating because he controlled the atmosphere of the room with humor and wit; his challenges were often delivered in American 'straight talk' and provocative questions were posed with an impish smile. For the students who had taken the leap of faith and followed him East, he had become as much a totemic figure as an advisor, and we were eager to demonstrate that we could meet the high standards he had set for academic discussion. Our fledgling thoughts were subjected to the same degree of scrutiny as the most distinguished guests, and we learned to brace ourselves for his incisive interventions following our contributions.

At the CCS, the 'charisma process' (Bartmanski, 20I2: 43I) entered another stage. Alexander's live performances of intellectual bravura were regularly attended by an audience that extended beyond the immediate circle of the converted. As a student, it was both daunting and inspiring to be situated at the cutting edge, critiquing research before it had even entered the literature. During the rest of my time at Yale, our analytic arsenal in the battle against weak programs expanded significantly with the introduction of social perfor- 
mance, civil sphere theory, and cultural trauma. We also accumulated allies and sympathizers to the cause; the CCS website listed dozens of fellows from around the world and at every stage of the academic career.

The institutionalization of the strong program continued at an impressive rate after I finished my degree at Yale and changed my status from 'PhD Candidate' to 'CCS faculty fellow.' A full array of publishing initiatives is currently associated with the CCS, including several book series, a journal and a handbook; the CCS also participates in various collaborative projects with researchers at other international universities. The strong program has become globalized through the establishment of research centers in Sweden, the Czech Republic and China. These developments are part of a broader maturation of the sub-discipline of cultural sociology. As Alexander's problematic found wider resonance and appeal beyond the American context, cultural sociology research networks grew in number and size. Today, research in cultural sociology finds a warmer reception in the mainstream of the discipline. These are encouraging signs, but they should not be taken as indications that the strong program has achieved its aims, or that the iconization of Alexander is complete.

The strong program's potential to advance social theory is far from exhausted. The framework Alexander proposed remains productive, but it has not been perfected, and several challenges remain. To take one example, the emotions and affect have been chronically under-theorized in the strong program. This is surprising given that the emotions are implicated in most, if not all, its central themes and topics (e.g. cultural trauma, war, social movements, social integration, political scandal, art and music). The tendency to focus on the cognitive meanings involved in interpretation, rather than emotional sensibility, may have resulted from the need to differentiate and distance the strong program from interactionist theories. ${ }^{\mathrm{I}}$ Goffman and Collins, in particular, were found wanting because they "posit[ed] a mechanistic and often cynical model of human interaction and emotion, one that failed to theorize a cultural realm that could regulate, and not only fall prey to or emerge from, moral calculus, bodily display and emotional need" (Smith \& Alexander, 2005: 8). With the strong program's identity now firmly established, there is no reason to continue avoiding the role of the emotions. Exploring the affective dimension can only enrich explanations of culture's causal force and help to specify "in detail just how culture interferes with and directs what actually happens" in social life (Alexander \& Smith, 2003: I4).

Another issue cultural sociologists should consider is the optimism often implied in arguments concerning meaning, the sacred, the civil sphere and enchantment in contemporary social life. This is not to suggest that scholars working in the strong program have shied away from studying disasters, horrors, injustice and crises, or that they have sidestepped the problems of power, inequality and incivility, either empirically or theoretically. Neither am I refut- 
ing Holmes (20I6) by insisting that sociology must be a pessimistic endeavor. My point is that cultural sociologists must resist the tendency for more difficult topics to be cordoned off in their own separate strand of research, and that we must be more careful about selecting cases that can appear to guarantee a positive narrative trajectory. To put it differently, cultural sociology should continue studying the "stars of the social universe" (Alexander, Bartmanski \& Giesen, 20I 2: 7) but also explain how some stars transform into black holes. Alexander has already pointed us in the right direction with The Dark Side of Modernity (Alexander, 2013), but his insight regarding the intertwining of good and evil is ripe for further development and wider application.

I raise these issues with my fellow cultural sociologists not only because they could further refine the strong program and yield significant research; they are also increasingly urgent matters given recent developments in the social world. As a former resident of the United States and a recent arrival to the United Kingdom, I am more attuned to what is happening in these societies, but the dramatic shift in political culture is hardly restricted to these regions. Nationalism, racism, xenophobia, and other divisive forces no longer occupy the margins. Anxiety as well as intellectual confusion are on the rise. Has fascism made a comeback? Is democracy dead? Can liberalism be renewed? Will international cooperation fail? Alexander's thought offers the guidance sought in approaching these questions, but it is up to us to deploy these ideas and make sense of our fragmenting social situation in a way that allows its ideational power to be fully realized. If we are successful, then the iconization of Alexander will be complete.

Lisa McCormick is Lecturer in Sociology at the University of Edinburgh. She is the author of Performing Civility (20I5), the first study analysing the social aspects of international classical music competitions. She has also published articles in Cultural Sociology, Ethnic and Racial Studies, Contemporary Social Science and the Chopin Review. Since 2016, she has been co-editor of the BSA journal Cultural Sociology; she also serves on the editorial boards of Sociological Theory, American Journal of Cultural Sociology, and Emerald Publishing's Death and Culture book series. 


\section{NOTE}

I I would like to thank Dmitry Kurakin for making this observation.

\section{BIBLIOGRAPHY}

Alexander, Jeffrey C. (2013). The dark side of modernity. Cambridge: Polity Press.

Alexander, Jeffrey C., Bartmanski, Dominik \& Giesen, Bernhard. (20I2). Iconic power: materiality and meaning in social life. New York: Palgrave Macmillan.

Alexander, Jeffrey C. \& Smith, Philip. (2003). The Strong Program in Cultural Sociology: Elements of a Structural Hermeneutics. In: The meanings of social life: a cultural sociology. Oxford/New York: Oxford University Press, p. II-26.

Bartmanski, Dominik. (2012). How to become an iconic social thinker: The intellectual pursuits of Malinowski and Foucault. European Journal of Social Theory, I5/4, p. 427-453.

Cordero, Rodrigo; Carballo, Francisco \& Ossandón, José. (2008). Performing Cultural Sociology: a conversation with Jeffrey Alexander. European Journal of Social Theory, II/4, p. 523-542.

Emirbayer, Mustafa. (2004). The Alexander School of Cultural Sociology. Thesis Eleven, 79/I, p. 5-I5.

Eyerman, Ron. (2004). Jeffrey Alexander and the cultural turn in social theory. Thesis Eleven, 79, p. 25-30.

Holmes, Mary. (2016). Sociology for optimists. SAGE.

Inglis, David; Blaikie, Andrew \& Wagner-Pacifici, Robin. (2007). Editorial: Sociology, culture and the 2Ist century. Cultural Sociology, I/I, P. 5-22.

Kurasawa, Fuyuki. (2004). Alexander and the cultural refounding of American sociology. Thesis Eleven, 79/I, p. 53-64.

Lynch, Gordon \& Sheldon, Ruth. (2013). The sociology of the sacred: A conversation with Jeffrey Alexander. Culture and Religion, I4/3, p. 253-267.

Smith, Philip \& Alexander, Jeffrey C. (2005). Introduction: the new Durkheim. In: The Cambridge Companion to Durkheim. Cambridge: Cambridge University Press, p. I-38.

Želinský, Dominik. (2018). Intellectual iconicity and the politics of understanding: Jan Patŏka among Unofficial Philosophers in Communist Czechoslovakia. CCSWorkshop, September I4, 2018. 
Palavras-chave

Carisma; sociologia cultural; iconicidade; performance; Jeffrey C. Alexander

Keywords

Charisma;

cultural sociology;

iconicity; performance;

Jeffrey C. Alexander.

\section{O PODER PERFORMATIVO DAS IDEIAS: JEFFREY} ALEXANDER COMO UM INTELECTUAL ICÔNICO

\section{Resumo}

Este artigo analisa o papel de Jeffrey Alexander no passado, no presente e no futuro do programa forte em sociologia cultural. O argumento central é que Alexander está se tornando um intelectual icônico, mas esse processo ainda se encontra inconcluso. A partir de observações de primeira mão reunidas através de meu pertencimento de longa data ao "grupo de Alexander", analiso a expansão da autoridade social e da influência intelectual do autor por meio da criação, da institucionalização e da globalização do programa forte - e a descrição de suas performances intelectuais carismáticas traz novos insights sobre o processo de iconização. Na conclusão, identifico alguns dos desafios que devem ser superados para um maior desenvolvimento teórico do programa forte e as condições necessárias para que o processo de iconização de Alexander se complete.

THE PERFORMATIVE POWER OF IDEAS: JEFFREY ALEXANDER AS AN ICONIC INTELLECTUAL

Abstract

This paper considers Jeffrey Alexander's role in the past, present and future of the strong program in cultural sociology. The central argument is that Alexander is becoming an iconic intellectual, but that the process is not yet complete. Drawing on first-hand observations gathered through my long-term affiliation with the "Alexander group", I trace the development of Alexander's social authority and intellectual influence through the establishment, institutionalization and globalization of the strong program. Descriptions of his charismatic intellectual performances provide further insight into iconization. The conclusion identifies some of the challenges that must be overcome for further theoretical development of the strong program, and the conditions that must be met for Alexander's iconization to reach completion. 